\title{
PERANCANGAN SISTEM INFORMASI JASA PENGIRIMAN BARANG BERBASIS WEB
}

\author{
Harry Dhika \\ Program Studi Teknik Informatika \\ Universitas Indraprasta PGRI \\ Email: dhikatr@yahoo.com \\ Lukman \\ Program Studi Teknik Informatika \\ Universitas Indraprasta PGRI \\ Email: 1kmnaja51@gmail.com \\ Aswin Fitriansyah \\ Program Studi Teknik Informatika \\ Universitas Indraprasta PGRI \\ Email: aswin_809@gmail.com
}

\begin{abstract}
ABSTRAK
Kajian dilakukan untuk mengasilkan sebuah aplikasi berupa sistem informasi jasa pengiriman barang berbasis web dan dibuat dengan metode Diagram Alir Data (DAD). Sebanyak 10 perusahaan swasta di DKI Jakarta menjadi sampel dalam pembuatan aplikasi berbasis web. Tujuan dari kajian ini untuk mengetahui seperti apa sistem yang digunakan dalam mengolah data-data di perusahaan jasa transportasi serta meminimalisir kendala yang dihadapi dalam pelaksanaan pengiriman barang dan jasa selain itu para pembaca dapat memahami penggunaan sistem informasi jasa pengiriman barang, untuk kepentingan kegiatan pengiriman barang. Aplikasi web yang dibuat memberikan informasi mengenai perjalanan barang dari daerah yang satu ke daerah yang lain sehingga pihak penyedia layanan atau pemilik barang dapat menggunakan informasi tersebut (tracking), memuat berbagai informasi pengiriman terkini, memuat informasi tarif, memuat profile dan memberikan informasi lain yang berguna bagi pelanggan. Hal ini dapat meminimalisir hilangnya barang, atau kecelakaan kerja lainnya dan barang yang dikirimkan dapat sampai di tempat tujuan sesuai dengan rencana awal pengiriman.
\end{abstract}

Kata kunci: Sistem informasi, jasa pengiriman barang, web.

\begin{abstract}
The study was conducted to make an application in the form of information system services and web-based delivery of goods made by the method of Data Flow Diagrams (DAD). A total of 10 private companies in Jakarta to be sampled in the manufacture of web-based applications. The purpose of this study to determine what kind of system is used to process the data in a transportation services company and minimize obstacles faced in the implementation of the delivery of goods and services other than that the reader can understand the use of information systems freight services, to the benefit of the shipping of goods. Applications created web provides information on the goods from one area to another area so that the provider of services or goods owners can use that information (tracking), contains a variety of information delivery date, loading rates, load profile and provide other helpful information for customers. This can minimize the loss of goods, or other workplace accidents and the goods can be delivered to their destination as planned early delivery.
\end{abstract}

Keywords: information systems, service delivery, web.

\section{PENDAHULUAN}

Saat ini perkembangan teknologi sudah mengarah kepada hal yang jauh lebih global seperti penggunaan web pada sebuah perusahaan. Perusahaan transportasi merupakan salah satu diantaranya, melakukan pengiriman barang dari perkotaan hingga pedesaan, dari sabang hingga merauke. Perusahaan tersebut tentunya membutuhkan sistem informasi manajemen baik dalam pengelolaan data, informasi atau profil perusahaan, hingga menampilkan biaya dan melakukan pemesanan jasa pengiriman barang yang 
keseluruhan aktifitasnya dapat dilakukan menggunakan halaman web. Oleh karena itu kebutuhan akan web profil atau manajemen saat ini sangatlah mendesak untuk kemajuan perusahaan. Untuk itu perlu dilakukan perancangan sistem informasi jasa pengiriman barang yang hanya dilakukan menggunakan atau berbasis web. Sehingga dapat mengakomodir kebutuhan akan permintaan jasa pengiriman barang yang semakin meningkat setiap waktunya.

Penggunaan diagram alir data sebagai suatu diagram yang memperlihatkan aliran data dari objek sumber atau nilai masukan melewati suatu proses yang kemudian diubah menjadi suatu nilai keluaran maupun disimpan dalam tempat penyimpanan sementara merupakan metodologi yang digunakan dalan mengelola data yang diambil dari perusahaan. Dalam menggunakan diagram aliran data memerlukan beberapa simbol, diantaranya: entitas, merupakan objek aktif yang mengendalikan aliran data dengan memproduksi serta mengkonsumsi data yang digambarkan dengan empat persegi-panjang, diberi label atau nama yang sesuai dengan kata benda, serta dapat digunakan beberapa kali dalam suatu diagram aliran data untuk menghindari adanya persilangan aliran data, menghubungkan keluaran dari suatu objek atau proses yang terjadi pada suatu masukan yang digambarkan dengan tanda panah dan diberi label yang menunjukan seseorang, tempat atau sesuatu yang digambarkan dalam kata benda. Proses, adalah sesuatu yang melakukan transformasi terhadap data digambarkan oleh sebuah bujur sangkar dengan sudut membulat yang digunakan untuk menunjukkan adanya proses transformasi perubahan data dan diberi label yang berbeda untuk aliran data masuk dan keluar untuk memahami proses yang sedang terjadi. Data storage, merupakan penyimpanan data sementara yang digambarkan oleh simbol bujur sangkar dengan ujung terbuka sebagai penunjuk tempat penyimpanan untuk data-data yang memungkinkan penambahan dan perolehan data [3][7]. Sistem adalah sekelompok unsur yang erat hubungannya satu dengan yang lain, yang berfungsi bersama-sama untuk mencapai tujuan tertentu [7]. Sedangkan dalam kamus komputer karangan menjelaskan bahwa sistem adalah suatu jaringan kerja dari prosedur-prosedur yang saling berhubungan, berkumpul bersama-sama untuk melakukan suatu kegiatan atau untuk menyelesaikan suatu sasaran tertentu [1].

HTML mempunyai kepanjangan dari Hyper Text Markup Language, yaitu suatu bahasa pemograman hyper text. Html memiliki fungsi untuk membangun kerangka ataupun format web berbasis html [8]. PHP (Hypertext Preprocessor) adalah bahasa scripting server-side, artinya dijalankan di server, kemudian outputnya dikirimkan ke client (browser). PHP digunakan untuk aplikasi web dan mendukung banyak databases yaitu Mysql, Informix, Oracle, Sybase, Solid, PostgreSQL, Generic ODBC, dll.) [9].

Web Server adalah suatu program komputer yang mempunyai tanggung jawab atau tugas menerima permintaan HTTP dan komputer klien, yang di kenal dengan nama web browser dan melayani mereka dengan menyediakan respon HTTP berupa konten data, biasanya halaman web yang terdiri dari dokumen HTML dan objek terkait seperti gambar dan lain-lain [9]. MySQL merupakan databases yang sangat popular. Beberapa keuntungan yang dimiliki MySQ1 yaitu: bersifat open source, menggunakan bahasa $S Q L$ (structure query language), super performance dan reliable, Mudah dipelajari, mampu bekerja dilintas platform dan multi user [8].

Kajian dilakukan dengan metode hubungan kausal yaitu metode sebab akibat dari beberapa variabel yang diamati dan diteliti, pada umumnya metode ini dikenal dengan nama explanary reaserch atau confirmmatory research dengan tujuan pembuktian hipotesis hasil dari survei yang dilakukan langsung. Penelitian eksplanatori (explanatory research) merupakan kajian yang berusaha menjelaskan hubungan kausal antara variabel-variabel melalui pengujian hipotesis yang telah dirumuskan [10]. Dengan metode yang ada, akan dilakukan analisa kajian terhadap sistem informasi, jasa pengiriman, dan web.

\section{PEMBAHASAN}

\subsection{Obyek}

Kajian ini memiliki sasaran pada beberapa perusahaan jasa pengiriman barang di wilayah DKI Jakarta yang menggunakan web base sebagai media dalam melaksanakan pekerjaannya.

\subsection{Tempat dan Waktu}

Penelitian ini dilakukan diwilayah DKI jakarta atau di lingkungan perusahaan yang ada di wilayah Jabodetabek dan penelitian ini berlangsung selama 2 (dua) tahun.

\subsection{Sampel atau Responden}

Sampel merupakan sebagian dari populasi yang karakteristiknya hendak diteliti dan dianggap bisa mewakili keseluruhan populasi (jumlahnya lebih sedikit daripada jumlah populasinya. Sedangkan 
sampling adalah suatu macam cara pengumpulan data yang sifatnya tidak menyeluruh artinya tidak mencangkup seluruh obyek peneleitian (populasi) akan tetapi hanya sebagaian dari populasi saja yaitu hanya mencakup sample yang diambil dari populasi tersebut.

\subsection{Studi Pustaka}

Studi kepustakaan bertujuan untuk mempelajari dan memahami dasar teori yang berhubungan dengan analisa kebutuhan yang telah dilakukan. Pengumpulan data dilakukan dengan mencari dan mendapatkan data secara teoritis melalui literatur-literatur, jurnal penelitian, bahan kuliah, dan sumber lainnya dari internet yang berhubungan dengan materi kajian penerimaan sistem informasi/teknologi informasi, khususnya terkait transportasi jasa pengiriman barang dan perancangan sistem informasi berbasis web.

\subsection{Kuisioner}

Pelaksanaan kuisioner dimaksudkan untuk mendapatkan data yang dibutuhkan dalam penelitian. Kuisioner bersifat closed question yang berupa pertanyaan-pertanyaan yang telah dibuat atau disusun. Kuisioner ini mempunyai tujuan untuk mendapatkan gambaran dari responden tentang pengetahuan akan jasa pengiriman barang dan informasi tentang penggunaan aplikasi secara umum yang ada pada perusahaan mereka.

Data yang didapatkan dari survey dengan membagikan kuesioner akan dianalisis dengan metode statistik multivariat, diolah dengan menggunakan software statistik. Dilakukan analisa pada sepuluh perusahaan didaerah DKI Jakarta dengan melakukan teknik wawancara, melakukan diskusi dan tanya jawab kepada para pengembang web didalam perusahaan tersebut hingga dari keseluruhan informasi yang diperoleh terbentuklah diagram alir data secara garis besar atau diagram konteks yang meiliki beberapa entitas yakni pelanggan yang melakukan pemesanan jasa pengiriman barang atau melakukan order melalui web, divisi administrasi yang mengelola data dan memanajemen kegiatan pengiriman, divisi pengawasan melakukan monitoring pengiriman barang, divisi perjalanan yang melakukan pengiriman barang, dan terakhir direktur sebagai penerima laporan kegiatan.

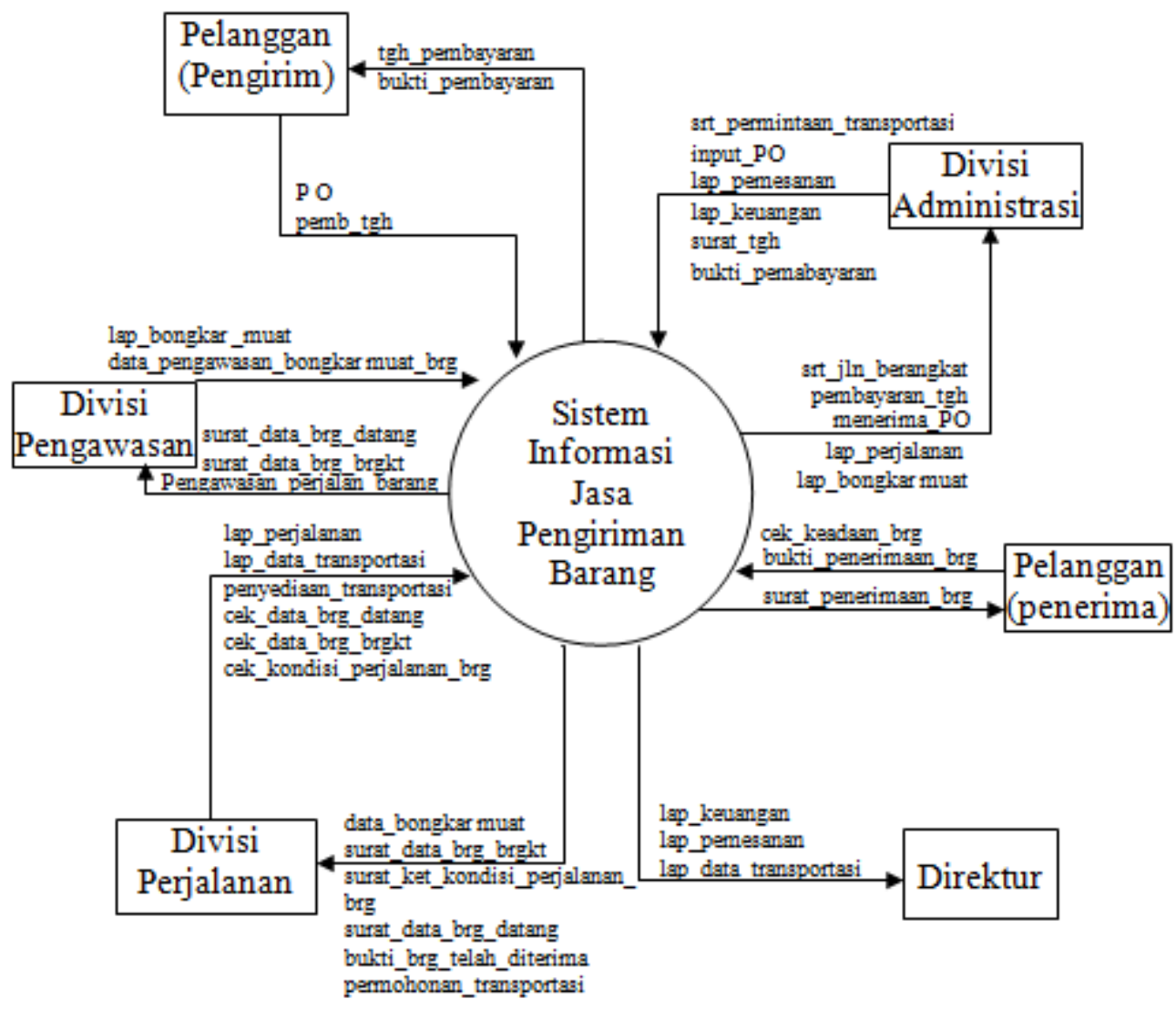

Gambar 1. Diagram Konteks Sistem Informasi Jasa Pengiriman Barang 
Gambar 1. memperlihatkan beberapa entitas terkait dengan proses utama secara garis besar melakukan tugasnya dengan sistem dan kembali kepada entitas lainnya. Dalam hal ini proses dilihat secara keseluruhan, Informasi dapat diketahui langsung oleh pelanggan terhadap kondisi pengiriman barang sehingga dapat melakukan monitoring setiap saat.

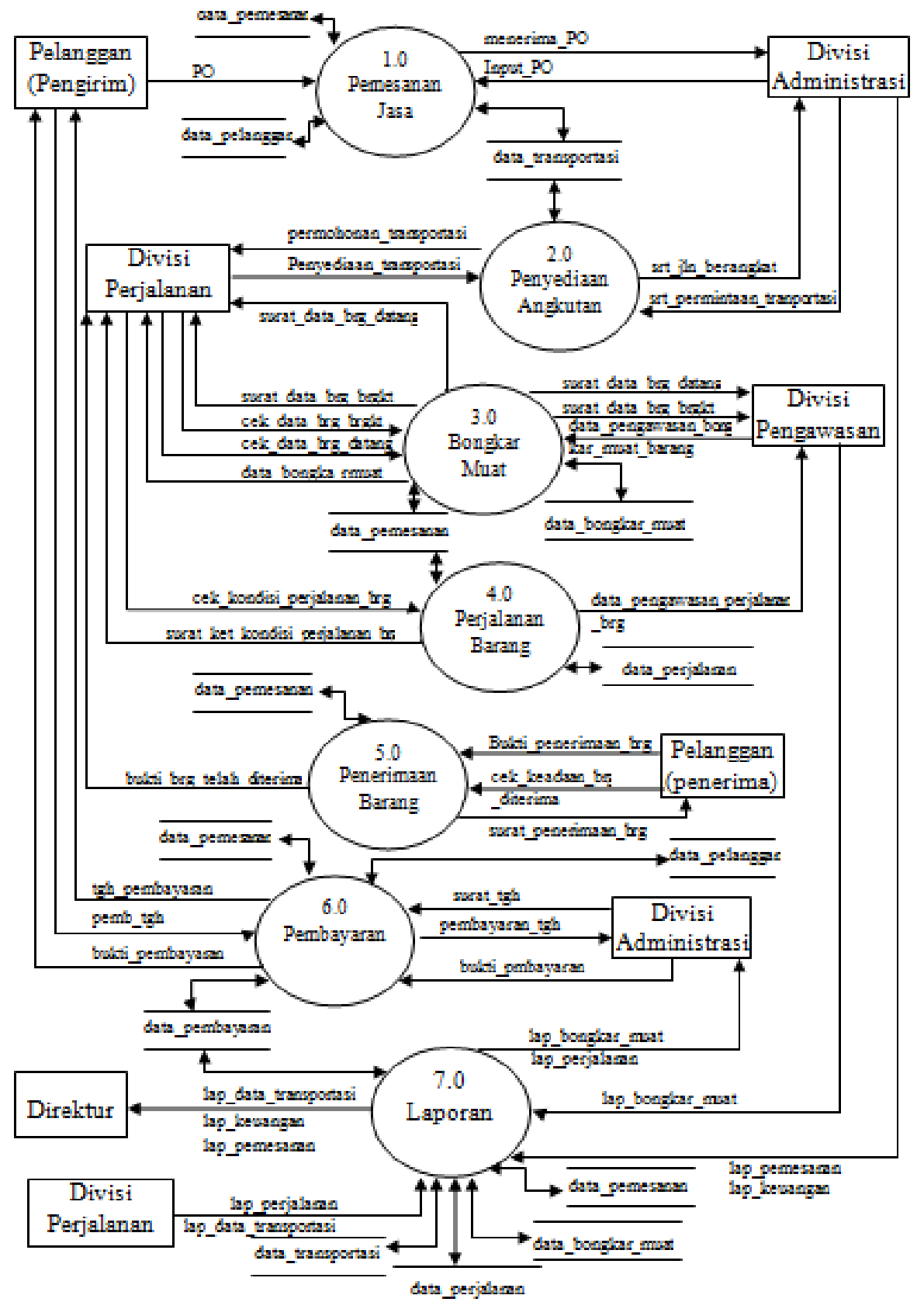

Gambar 2. Diagram Nol Sistem Informasi Jasa Pengiriman Barang

Gambar 2. Memberikan penjabaran secara detail dari gambar 1. Dengan beberapa proses, diantaranya proses 1.0 pemesanan jasa, proses 2.0 penyediaan angkutan, proses 3.0 bongkar muat, proses 4.0 perjalanan barang, proses 5.0 pengiriman barang, proses 6.0 pembayaran, dan terakhir proses 7.0 laporan. Databases yang digunakan dari gambar 2. adalah data pemesanan, data pelanggan, data transportasi, data bongkar muat, data perjalanan, data pembayaran. Seluruh proses saling bersinergi dengan seluruh entitas yakni pelanggan pengirim, pelanggan penerima, divisi administrasi, divisi pengawasan, divisi perjalanan, dan direktur. Dalam melakukan proses, pada gambar 2 setiap entitas terhubung dengan proses dan proses terhubung dengan database, seluruhnya bersinergi. 


\subsection{Rancangan Masukan}

a. $\mathrm{PO}$

$\begin{array}{ll}\text { Nama Masukan } & \text { : PO } \\ \text { Sumber } & \text { : Pelanggan } \\ \text { Distribusi } & \text { : Divisi Administrasi Melalui } \\ & \text { Web } \\ \text { Fungsi } & \text { : Sebagai Bukti permintaan Jasa } \\ & \text { Pengiriman Barang } \\ \text { Media } & \text { : Kertas Print Out } \\ \text { Rangkap } & \text { : Dua Lembar } \\ \text { Periode } & \text { : Ketika Pelanggan Memesan } \\ & \text { Jasa Pengiriman Barang } \\ \text { Bukti Penerimaan } & \text { Barang } \\ \text { Nama Masukan } & \text { : Bukti Penerimaan Barang } \\ \text { Sumber } & \text { : Pelanggan Melalui Web } \\ \text { Distribusi } & \text { : Melalui Web } \\ \text { Fungsi } & \text { : Sebagai Bukti permintaan Jasa } \\ & \text { Pengiriman Barang } \\ \text { Media } & \text { : Kertas Print Out } \\ \text { Rangkap } & \text { : Dua Lembar } \\ \text { Periode } & \text { : Ketika Barang Sampai }\end{array}$

\subsection{Rancangan Keluaran}

a. Surat Jalan Berangkat

Nama Keluaran : Surat Jalan Berangkat

Sumber : : Divisi Administrasi

Distribusi : Divisi Perjalanan

Fungsi : Sebagai surat izin melakukan perjalanan pegiriman barang.

Media : Kertas

Rangkap $\quad: 2$ lembar

Periode : : ketika PO sudah disetujui dan barang siap berangkat.

b. Surat Tagihan

Nama Keluaran : Surat Tagihan

Sumber : : Divisi Administrasi

Distribusi : Pelanggan (pengirim)

Fungsi : Sebagai surat penagihan biaya jasa pengiriman barang

Media : Kertas

Rangkap : dua lembar

Periode : Ketika barang telah sampai kepada pelanggan (penerima).

c. Bukti Pembayaran

Nama Keluaran : Bukti Pembayaran

Sumber : Divisi Administrasi

Distribusi : Pelanggan (pengirim)

Fungsi $\quad:$ Sebagai bukti bahwa tagihan telah dibayar

Media : Kertas

Rangkap : dua lembar

Periode : Setelah melakukanPembayaran

d. Laporan Pemesanan

Nama Keluaran : Laporan Pemesanan

Sumber : : Divisi Administrasi

Distribusi : Direktur

Fungsi : Sebagai laporan kegiatan pemesanan jasa transportasi.

Media : Kertas

Rangkap : dua lembar

Periode $\quad: 1$ bulan sekali. 
e. Laporan Pembayaran

Nama Keluaran : Laporan Pembayaran

Sumber

: Divisi Administrasi

Distribusi

: Direktur

Fungsi

Media

: Sebagai laporan kegiatan pembayaran jasa transportasi.

Rangkap

: Kertas

Periode

: dua lembar

f. Laporan Bongkar Muat

Nama Keluaran : Laporan Bongkar Muat

Sumber

: Divisi Pengawasan

Distribusi

: Direktur

Fungsi

Media

: Sebagai laporan kegiatan bongkar muat jasa transportasi.

Rangkap

: Kertas

Periode

: dua lembar

g. Laporan Data Transportasi

Nama Keluaran : Laporan Data Transportasi

Sumber

Distribusi

: Divisi Perjalanan

Fungsi

Media

: Direktur

Rangkap

: Sebagai laporan penggunaan alat-alat transportasi.

Periode

: Kertas

: dua lembar

h. Laporan Perjalanan

Nama Keluaran : Laporan Perjalanan

Sumber

: Divisi Perjalanan

Distribusi

: Direktur

Fungsi

Media

: Sebagai laporan kegiatan perjalanan jasa transportasi.

Rangkap

: Kertas

Periode

: dua lembar

: 1 bulan sekali.

\subsection{Rancangan Antar Muka}

Rancangan antar muka atau dialog layar merupakan rancang bangun percakapan antara pemakai dengan komputer yang terdiri dari proses memasukkan data ke sistem kemudian menampilkan kembali output informasi kepada pemakai dengan uraian sebagai berikut:

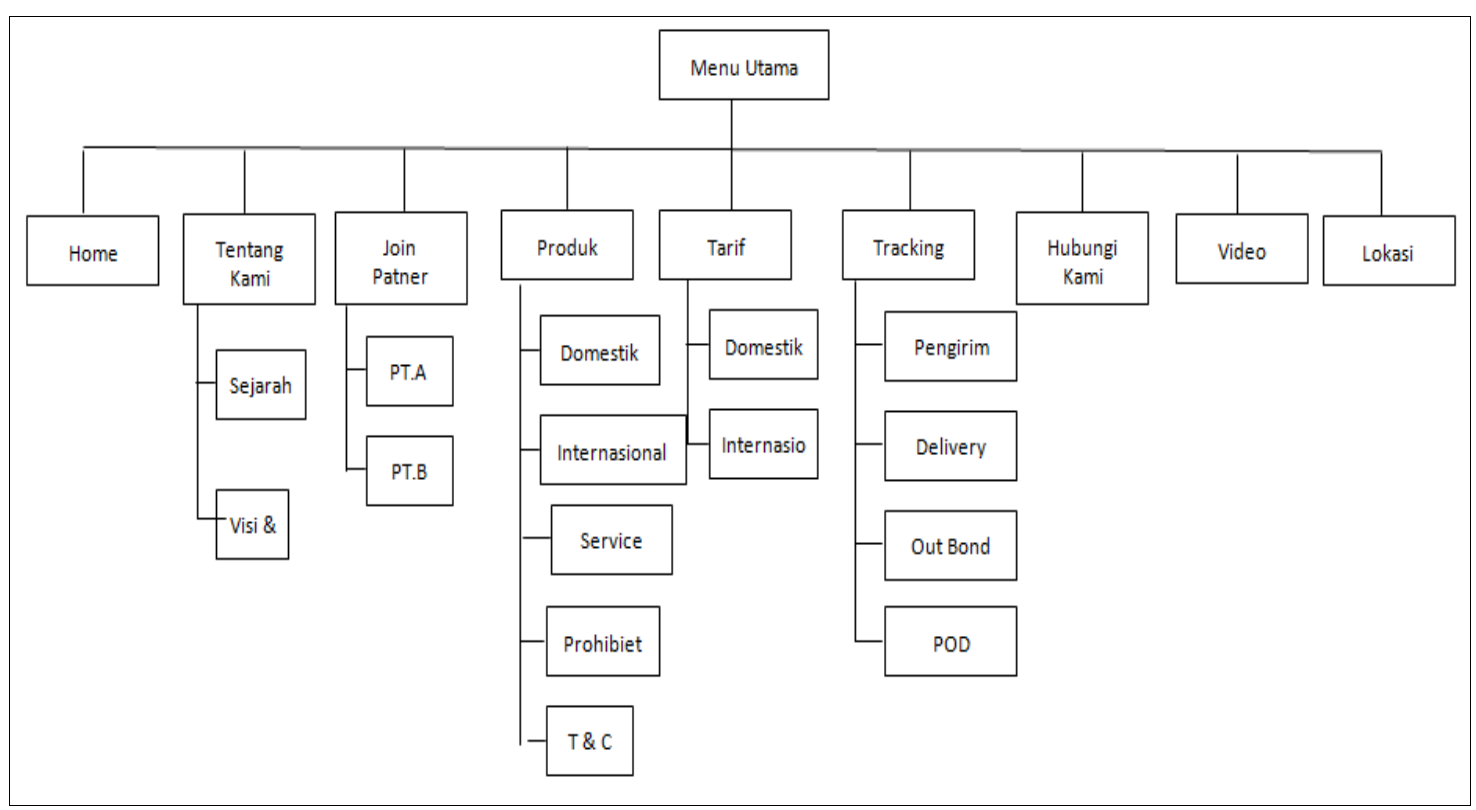

Gambar 3. Rancangan Antar Muka atau Dialog Layar 
Pada gambar 3. Menu utama terdiri dari beberapa sub-menu lainnya diantaranya Home, Tentang Kami, Joint Partner, Produk, Tarif, Tracking, Hubungi Kami, Video dan terakhir Lokasi. Dalam menu tentang kami terdapat Sejarah dan Visi serta Misi perusahaan. Di dalam menu Joint Parnet terdapat sub mеnu PT. A dan PT.B. Didalam menu Produk terdapt beberapa sub menu diantaranya Domestik, Internasional, Servie, Prohibiet dan T\&C. Didalam sub mеnu Tarif terdapat beberapa menu dinataranya tarif domestik dan tarif Internasional. Didalam sub menu Tracking terdapat beberapa menu diantaranya menu pengirim, menu tracking, menu Outbond dan menu POD.

\subsection{Rancangan Tampilan}

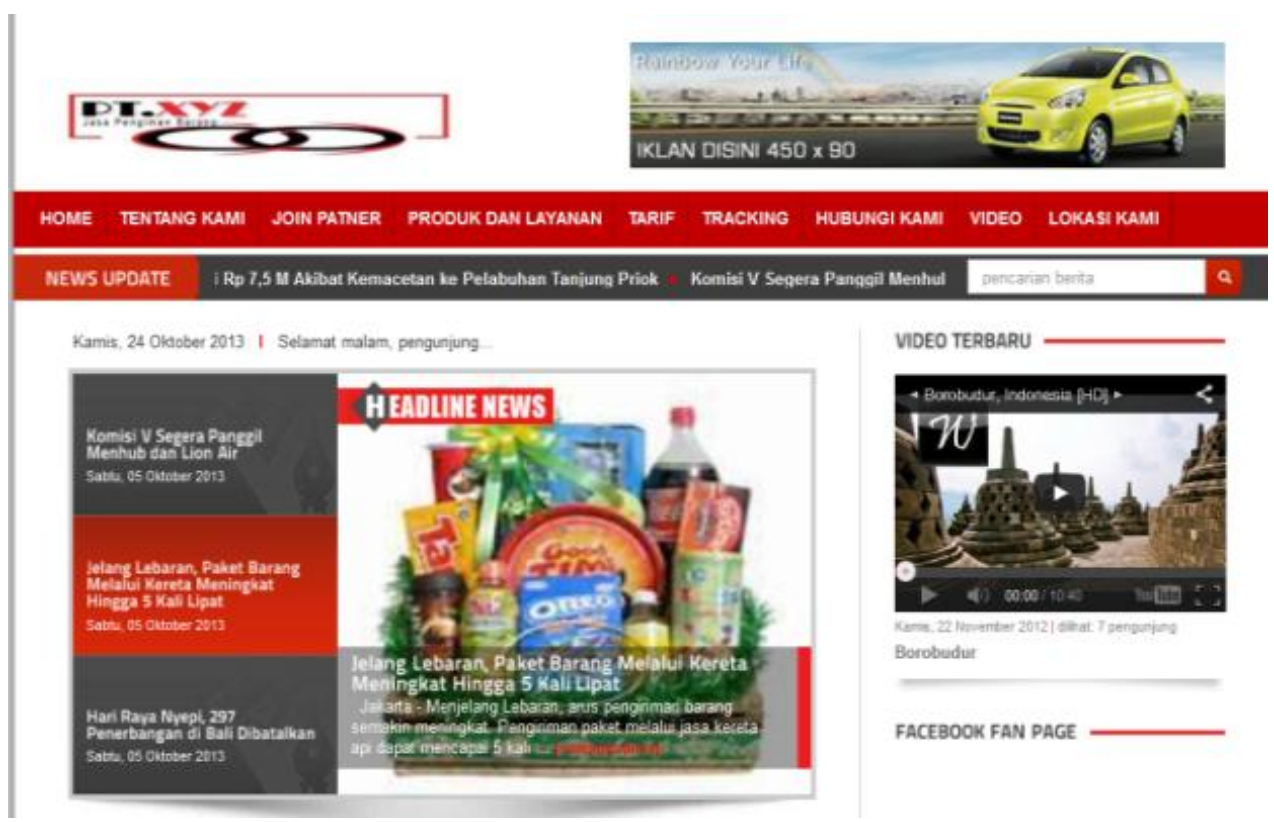

Gambar 4. Halaman Awal

Rancangan ini terdapat pada awal program. Ketika membuka awal program terdapat menu berita terbaru, video, facebook fan page, customer service yaitu yahoo messenger. Dalam berita terbaru terdapat: segala aktifitas saat ini yang sedang tren didunia informasi. Terdapat pula berita utama, memuat tentang penggolongan berita teknologi, penggolongan berita pengiriman, dan link profil tentang kami serta menampilkan juga link produk dan layanan.

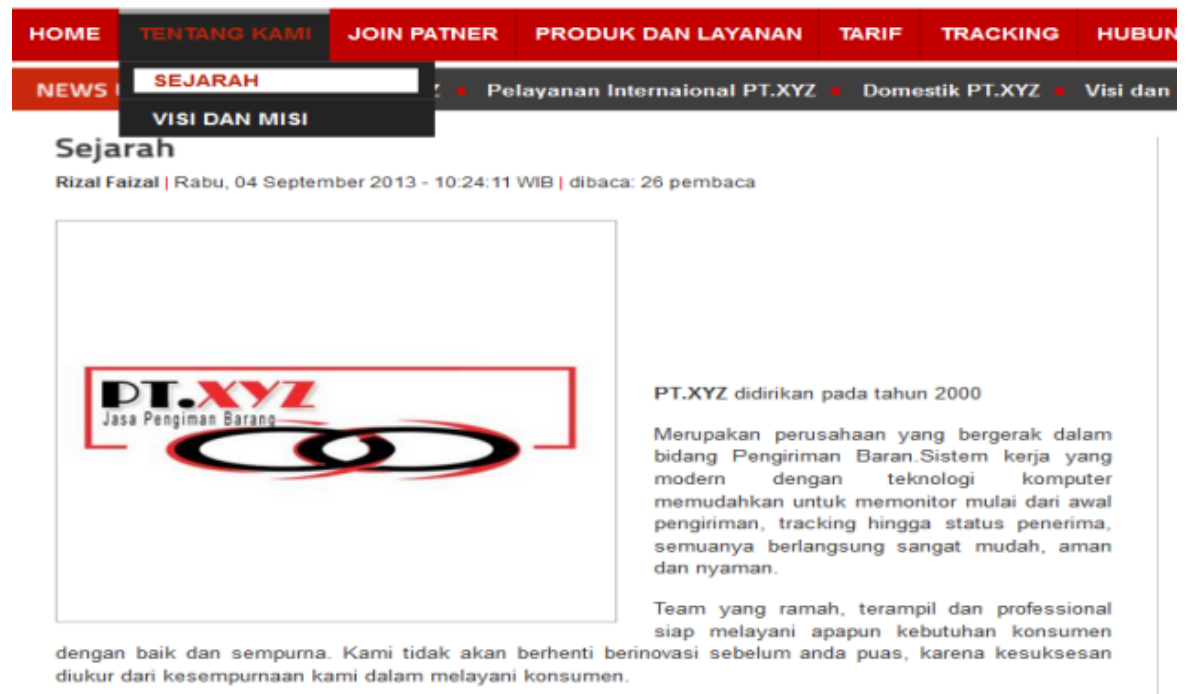

Gambar 5. Halaman tentang kami

Rancangan ini terdapat pada Menu tentang kami. Dimana ketika mengklik menu "tentang kami” lalu klik "sejarah". Halaman ini menjelaskan tentang berdiri nya perusahaan PT. XYZ. Merupakan perusahaan yang bergerak dalam bidang Pengiriman Barang. Sistem kerja yang modern dengan teknologi komputer 
memudahkan untuk memonitor mulai dari awal pengiriman, tracking hingga status penerima, semuanya berlangsung sangat mudah, aman dan nyaman.

Team yang ramah, terampil dan professional siap melayani apapun kebutuhan konsumen dengan baik dan sempurna. Kami tidak akan berhenti berinovasi sebelum anda puas, karena kesuksesan diukur dari kesempurnaan kami dalam melayani konsumen.

Pada halaman tersebut juga terdapat halaman visi dan misi diantaranya: kami ingin menyederhanakan hidup pelanggan, kami membuat pelanggan, karyawan dan investor lebih sukses. kami berkontribusi positif terhadap dunia, kami selalu menunjukkan rasa hormat saat mencapai hasil kami

\section{KESIMPULAN}

Berdasarkan deskripsi data penelitian dan setelah dikalukan analisis serta pengujian maka dapat disimpulkan secara garis besar adanya perancangan sistem informasi jasa pengiriman barang berbasis web sangat membantu. Dapat melakukan login, atau memonitoring keberaan barang pada saat pengiriman berlangsung. Tercapainya tujuan utama dalam penelitian ini yakni:

a. Merancang dan membuat sebuah sistem informasi jasa pengiriman barang.

b. Memberikan pengenalan, pemahaman tentang pembuatan aplikasi jasa pengiriman barang.

\section{DAFTAR PUSTAKA}

[1] Febrian, Jack. 2004. Kamus Komputer dan Istilah Teknologi Informasi. Penerbit Informatika Bandung. Bandung.

[2] Hermawan, ferry, dkk. 2010. Jurnal: Pengembangan Angkutan Uumum didaerah Suburban Kota Semarang Berbasis Sistem Informasi Geografis. Bandung: Aptikom.

[3] Kendal Kendal. 2007. Analisis dan Perancangan Sistem: Edisi ke lima-jilid 1. Jakarta: Indeks.

[4] Prabowo, Nugroho Agung, dkk. 2010. Sistem Pendukung Keputusan Sebagai Analisis Pemilihan Rekanan Pengadaan Barang Dan Jasa di Politeknik Negeri Semarang. Bandung: Aptikom

[5] Risnandar, Pratama Tirta Wulandari W. K. 2010. Integrasi Teknologi Informasi dan Supply Chain Management (Studi Kasus: PT. X, West Java). 2010. Bandung : Aptikom.

[6] Sutabri, Tata. 2004. Analisa Sistem Informasi. Yogyakarta: Penerbit Andi.

[7] Saputra, Agus. 2012. Sistem Informasi Nilai Akademik untuk Panduan Skripsi. Jakarta: Alex Media Komputindo.

[8] Madcom. 2013. Kupas Tuntas adobe Dreamweaver dengan pemograman PHP dan MYSQL CS6. Yogyakarta: Penerbit Andi. 